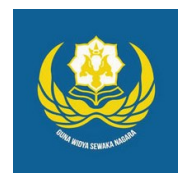

Jurnal Analogi Hukum

Journal Homepage: https://ejournal.warmadewa.ac.id/index.php/analogihukum

\title{
Perlindungan Hukum Terhadap Pemegang Saham Minoritas Pada Perseroan Terbatas Yang Melakukan Merger
}

\author{
I Kadek Sridana*, I Nyoman Putu Budiartha dan I Putu Gede Seputra \\ Fakultas Hukum, Universitas Warmadewa, Denpasar, Bali-Indonesia \\ *sridana@gmail.com
}

How To Cite:

Sridana, I, K., Budiartha, I, N, P., Seputra, I, P, G. (2020). Perlindungan Hukum Terhadap Pemegang Saham Minoritas Pada Perseroan Terbatas Yang Melakukan Merger. Jurnal Analogi Hukum. 2(1). 59-62. Doi: http://dx.doi.org/10.22225/.2.1.1618.59-62

\begin{abstract}
Mergers can be said as a strategy or one way to increase a company, therefore there is a need for legal protection for minority shareholders if they do not agree with the merger but the merger is still implemented, and the shareholders are forced to accept the merger. The formulation of the problem in this case is (1) what is the position of the minority shareholders for the limited liability company that merges? (2) What is the legal protection of minority shareholders in a limited liability company that merges? This research method uses a normative research method by approaching the problem in the form of a draft law that relates to the problem under study. The sources of legal material to be used are sourced from research, the literature in the form of primary legal material and secondary legal material. The result of this study are the legal position of the minority shareholders of the company (PT) that carried out the merger has been regulated in Law number 40 of 2007 concerning Limited Liability Companies and in Government Regulation Number 27 of 1998 concerning merger, consolidation and takeover of the interests of minority shareholders. In general, the law of limited liability companies is a guideline in the framework of protecting minority shareholders. Protection of minority shares is one of the important things, especially when the company conducts legal actions such as mergers, both preventive legal protection and repressive legal protection.
\end{abstract}

Keywords: Legal protection, shareholders, mergers

Abstrak- Merger dapat dikatakan sebagai strategi atau salah satu cara untuk meningkatkan suatu perusahaan oleh karena itu perlu adanya perlindungan hukum terhadap pemegang saham minoritas apabila mereka tidak setuju dengan merger namun merger tetap dilaksanakan, dan pemegang saham tersebut dipaksakan untuk menerima merger tersebut. Adapun rumusan masalah dalam hal ini (1) Bagaimanakah kedudukan pemegang saham minoritas bagi perseroan terbatas yang melakukan merger? (2) Bagaimanakah perlindungan hukum terhadap pemegang saham minoritas pada perseroan terbatas yang melakukan merger? Metode penelitian ini menggunakan metode penelitian normatif dengan melakukan pendekatan masalah berupa pedekatan perundang-undangan yang berkaitan dengan masalah yang dikaji. Adapun sumber bahan hukum yang akan digunakan yakni bersumber dari penelitian, kepustakaan berupa bahan hukum primer dan bahan hukum sekunder. Adapun hasil dari penelitian ini adalah kedudukan hukum pemegang saham minoritas terhadap perusahaan (PT) yang melakukan merger, sudah diatur dalam Undang-undang nomor 40 tahun 2007 tentang Perseroan terbatas serta dalam Peraturan pemerintah Nomor 27 Tahun 1998 tentang penggabungan, peleburan, dan pengambilalihan tentang kepentingan pemegang saham minoritas. Secara umum hukum perseroan terbatas menjadi pedoman dalam rangka perlindungan pemegang saham minoritas. Perlindungan terhadap saham minoritas merupakan salah satu hal yang penting terutama saat persroan melakukan perbuatan hukum seperti merger baik perlindungan hukum secara preventif maupun perlindungan hukum secara represif.

Kata kunci: Perlindungan hukum, Pemegang saham, Merger

\section{Pendahuluan}

Salah satu kewajiban dari pemerintah untuk mengembangkan bisnis usaha dengan cara memberi arahan atau petunjuk serta membimbing dengan maksud agar supaya berkembangnya usaha-usaha dari yang terkecil. Selain itu juga mendorong adanya perubahan pertumbuhan yang pada dasarnya merupakan fakta yang nyata bahwa investasi dari yang terkecil sampai dengan yang besar sangat perlu dalam memenuhi biaya pembangunan yang 
berkelanjutan.

PT adalah suatu perkumpulan modal yang berbeda dengan perkumpulan-perkumpulan perdata, firma dan CV yang tiada lain adalah perkumpulan orang-orang. Maka dari itu Perseroan Terbatas menarik minat investor atau penanam modal untuk menanamkan modalnya, bahkan Perseroan Terbatas dilihat pada tahuntahun belakangan ini sudah menarik perhatian dunia usaha dikarenakan oleh perkembangan haknya dalam hidup perekonomian di banyak Negara. Salah satu usaha yang bisa dilakukan dalam mempertahankan kelangsungan kegiatan usaha yaitu suatu perseroan harus pintar dalam mencari dan menggali sumber-sumber dana, adapun salah satu cara lain yang dilakukan oleh pihak perseroan salah satunya yaitu melalui penggabungan atau yang lebih dikenal dengan merger. Merger merupakan suatu usaha yang dilakukan dengan menggabungkan dua perseroan yang nantinya satu perseroan harus tetap berjalan dengan nama baru, dengan catatan perseroan yang lainnya harus dilenyapkan dari semua nama dan dananya dimasukkan kedalam satu perseroan yang masih berjalan dengan nama baru itu. Sehingga dapat disimpulkan bahwa merger merupakan penggabungan dua perusahaan dimana perusahaan satu masih berdiri dan yang menggabungkan diri bubar demi hukum (Rastuti, 2015).

Merger dapat dikatakan sebagai strategi atau salah satu cara untuk meningkatkan perusahaan, perusahaan-perusahaan yang melakukan strategi merger ini memiliki tujuan yang sama dan diharapkan dapat memberikan keuntungan yang lebih daripada sebelum menggabungkan diri. Disamping itu perusahaan yang melakukan merger biasanya adalah perusahaan yang mempunyai bisnis yang sama atau berkaitan erat, dan tentunya perusahaan yang sehat secara operasional. Sebagai target umum dari merger, yaitu peningkatan penjualan pasar, peningkatan pengembangan penemuan yang baru sebagai sarana investasi peningkatan persaingan serta sumber dana yang dimaksimalkan lagi dan pasokan bahan baku yang terjamin. Pelaksanaan merger ada berbagai macam pihak yang memiliki kepentingan dalam suatu Perseroan Terbatas, mereka yang berkepentingan adalah para karyawan, konsumen, masyarakat setempat, perekonomian secara luas dan salah satunya pemegang saham (Sutedi, 2015).

Shareholder atau yang lebih dikenal dengan pemegang saham merupakan orang yang menanamkan modalnya dan memiliki bagian besar saham yang dimilikinya. Undang- undang Nomor $40 \quad$ Tahun 2007 Tentang Perseroan Terbatas menyatakan, RUPS memiliki kedudukan yang lebih penting sebagai organnya perseroan yang mempunyai kekuasaan paling tinggi. Pemilik saham memiliki kelebihan untuk memberikan pengaruh pada suatu kebijakan tentang perseroan lewat cara RUPS ini membuat hasil keputusan itu akan mengikat bagi pihak-pihak yang mempunyai kepentingan, kecuali jika keputusan tersebut betentangan dengan Undang -undang maupun tujuan daripada perusahaan. Tanggung jawab dari pemegang saham pada hakikatnya terbatas karena hanya bertanggung jawab sampai jumlah saham yang dimiliki.

Pihak-pihak yang lemah saat proses merger harus dijamin kedudukannya yaitu salah satunya pemegang saham minoritas. Salah satu efek dari struktur melalui saham yaitu terciptanya struktur pemegang saham mayoritas dan minoritas. Pada dasarnya pemegang saham minoritas memiliki hak yang sama dengan pemegang saham mayoritas terutama pada hak suara tak terkecuali. Namun semakin banyak saham yang dimilikinya, maka dapat dikatakan semakin berkuasa ia dalam menentukan keputusan mengenai keberadaan dan jalannya suatu perseroan terbatas terutama jika perseroan terbatas tersebut melakukan merger. Hal ini membuat pemegang saham minoritas sulit terhindar dari tindakan yang merugikan pemegang saham minoritas sehingga pada akhirnya menimbulkan sengketa yang berujung gugatan di pengadilan apabila merger dari suatu perusahaan itu dilakukan tanpa persetujuan pihak pemegang saham minoritas.

Terkait dengan permasalahan hukum perlindungan terhadap pemegang saham minoritas dapatlah dirujuk sebagaimana terdapat dalam Undang-undang Nomor 40 Tahun 2007 Tentang Perseroan Terbatas. Selanjutnya diatur bagi pemegang saham yang tidak setuju pada merger dalam pasal 62 ayat (1) Undang-Undang Nomor 40 Tahun 2007 Tentang Perseroan Terbatas, pemegang saham yang bersangkutan dapat menuntut agar sahamnya dibeli dengan harga wajar, mengingat pemegang saham akan memiliki suara sebanding dengan banyaknya saham yang ditanamkan, jumlah pemegang saham minoritas pada prinsipnya harus mendapat perlindungan yang sewajarnya.

Penelitian terkait dengan penelitian sekarang telah dilakukan oleh (Asmawati, 2014) yang berfokus pada perlindungan hukum pemegang saham minoritas akibat merger bank menunjukkan bahwa perlindungan hukum pemegang saham minoritas akibat merger bank, 
belum terlindunginya secara penuh pemegang saham minoritas,jika bank tersebut melakukan merger,sedangkan prinsip yang dipergunakan dalam memberikan perlindungan berupa apparsial rehts dan prinsip super mayority.

Penjelasan diatas maka muncul persoalan bagi pihak yang lemah seperti pemegang saham minoritas dalam kegiatan merger. Perlindungan pemegang saham minoritas ini diperlukan apabila mereka tidak setuju dengan merger, dan merger tetap dilaksanakan maka pemegang saham tersebut dipaksakan untuk menerima merger tersebut.

Adapun rumusan masalah dalam hal ini: Bagaimanakah kedudukan pemegang saham minoritas bagi perseroan terbatas yang melakukan merger?, Bagaimanakah perlindungan hukum terhadap pemegang saham minoritas pada perseroan terbatas yang melakukan merger?

\section{Metode}

Tipe penelitian ini menggunakan kajian ilmu normatif. Khususnya tentang Hukum Perusahaan yang berkaitan dengan ketentuan Perseroan Terbatas dalam hubungan dengan pemegang saham minoritas dan merger.

Dalam suatu penelitian perlu adanya suatu pendekatan yang digunakan yaitu contoh dalam penelitian ini pendekatan yang digunakan yaitu pendekatan melalui perundang-undangan. Cara pendekatan ini dilakukan dengan suatu perundang-undangan ditelaah dan diteliti mengenai permasalahan yang berkaitan.

Sumber bahan hukum yang digunakan dalam penelitian ini yaitu : 1) bahan hukum primer merupakan bahan hukum yang bersifat mengikat dan memaksa. 2) Bahan hukum sekunder, yaitu bahan yang memberikan penjelasan tentang bahan hukum primer berupa dokumen-dokumen atau doktrin-doktrin yang ada hubungannya dengan objek masalah yang akan diteliti.

Karena penelitian ini adalah penelitian normatif, maka dalam pengumpulan datanya dilakukan dengan mencatat baik bahan hukum primer dan bahan hukum sekunder kemudian diindentifikasi dan diklasifikasi dapat digunakan sebagai bahan analisa.

\section{Hasil Penelitian dan Pembahasan}

\section{Kedudukan Pemegang Saham Minoritas Bagi Perseroan Terbatas yang Melakukan Merger}

Di dalam perusahaan perseroan terdapat 2 (dua) jenis pemegang saham yang sama-sama memiliki hak untuk ada dalam RUPS. Pemegang saham mayoritas adalah pemegang saham yang memiliki kepentingan untuk mengawasi suatu perusahaan karena kepemilikan saham yang lebih dari $50 \%$ saham (Jusup, 2011).

Kedudukan hukum pemegang saham minoritas terhadap perusahaan (PT) yang melakukan merger, sudah diatur dalam Undangundang nomor 40 tahun 2007 tentang Perseroan terbatas serta dalam Peraturan pemerintah Nomor 27 Tahun 1998 tentang penggabungan, peleburan, dan pengambilalihan tentang kepentingan pemegang saham minoritas. Namun yang menjelaskan bahwa suara pemegang saham minoritas dapat memiliki kedudukan yang sama dengan pemegang saham mayoritas apabila pemegang saham minoritas tersebut ikut serta dalam menjalankan keberlangsungan perusahaan baik itu secara langsung maupun tidak langsung.

Mengenai kedudukan hukum terhadap suara pemegang saham minoritas yang dikeluarkan pada saat RUPS diatur pula dalam Peraturan Bank Indonesia tahun 2010 tentang uji kepatutan dan kemampuan. RUPS memiliki kedudukan yang lebih penting sebagai organnya perseroan yang mempunyai kekuasaan paling tinggi. Pemilik saham memiliki kelebihan untuk memberikan pengaruh pada suatu kebijakan tentang perseroan lewat cara RUPS ini membuat hasil keputusan itu akan mengikat bagi pihak-pihak yang mempunyai kepentingan, kecuali jika keputusan tersebut betentangan dengan Undang-undang maupun tujuan daripada perusahaan.

Merger merupakan penggabungan dua perseroan yang kemudian menjadi satu perseroan yang mempunyai tujuan yang sama untuk meningkatkan suatu perseroan. Hal ini berarti ada pihak-pihak yang kedudukannya berubah setelah merger dilakukan salah satu pihak yang lemah yaitu pemegang saham minoritas.

Merger dapat dikatakan sebagai strategi atau salah satu cara untuk meningkatkan perusahaan, perusahaan-perusahaan yang melakukan strategi merger ini memiliki tujuan yang sama dan diharapkan dapat memberikan keuntungan yang lebih daripada sebelum menggabungkan diri. Disamping itu perusahaan yang melakukan merger biasanya adalah perusahaan yang mempunyai bisnis yang sama atau berkaitan erat, dan tentunya perusahaan yang sehat secara operasional. Sebagai target umum dari merger, yaitu dalam peningkatan 
penjualan pasar, peningkatan pengembangan penemuan yang baru sebagai sarana investasi, peningkatan persaingan serta sumber dana yang dimaksimalkan lagi dan pasokan bahan baku yang terjamin

\section{Perlindungan Hukum Terhadap Pemegang Saham Minoritas Pada Perseroan Terbatas yang Melakukan Merger}

Proses pelaksanaan merger ini perlu adanya perlindungan agar tidak terjadi tindakan -tindakan yang kemudian akan merugikan pihak yang lemah seperti pemegang saham minoritas. Pengaturan tentang hak dari pemegang saham minoritas dapat dilihat dari ketentuan-ketentuan dalam perundang-undangan.

Salah satu yang mengatur tentang perlindungan pemegang saham minoritas yaitu Undang-Undang Perseroan Terbatas. Hal ini membuat pemegang saham minoritas sulit terhindar dari tindakan yang merugikan pemegang saham minoritas sehingga pada akhirnya menimbulkan sengketa yang berujung gugatan di pengadilan apabila merger dari sauatu perusahaan itu dilakukan tanpa persetujuan pihak pemegang saham minoritas.

Terkait dengan permasalahan hukum perlindungan terhadap pemegang saham minoritas dapatlah dirujuk sebagaimana terdapat dalam Undang-undang Nomor 40 Tahun 2007 Tentang Perseroan Terbatas. Selanjutnya diatur bagi pemegang saham yang tidak setuju pada merger dalam pasal 62 ayat (1) Undang-Undang Nomor 40 Tahun 2007 Tentang Perseroan Terbatas, pemegang saham yang bersangkutan dapat menuntut agar sahamnya dibeli dengan harga wajar, mengingat pemegang saham akan memiliki suara sebanding dengan banyaknya saham yang ditanamkan, jumlah pemegang saham minoritas pada prinsipnya harus mendapat perlindungan yang sewajarnya. Secara Umum hukum perseroan terbatas menjadi pedoman dalam rangka perlindungan pemegang saham minoritas.

\section{Simpulan}

Dari penjelasan pendahuluan sampai dengan hasil penelitian dan pembahasan, maka dapat disimpulkan yaitu :

Mengenai kedudukan pemegang saham minoritas bagi perseroan terbatas yang melakukan merger yaitu bahwa Kedudukan hukum pemegang saham minoritas terhadap perusahaan (PT) yang melakukan merger, sudah diatur Undang-undang dalam menghadapi persaingan bisnis di era sekarang, pada umumnya perusahaan melakukan upaya-upaya untuk mempertahankan dan senantiasa mengembangkan diri. Untuk itu, agar terpenuhinya unsur keadilan, diperlukan suatu keseimbangan sehingga pihak pemegang saham minoritas tetap dapat menikmati haknya selaku mayoritas, termasuk mengatur perseroan.

Mengenai Peraturan yang mengatur tentang perlindungan pemegang saham minoritas yaitu Undang-undang Perseroan Terbatas. Secara umum hukum perseroan terbatas menjadi pedoman dalam rangka perlindungan pemegang saham minoritas. Perlindungan terhadap pemegang saham minoritas merupakan salah satu hal yang penting terutama perseroan melakukan perbuatan hukum seperti merger. Baik perlindungan hukum secara preventif seperti memberikan suatu upaya bagi pemegang saham yang tidak setuju terhadap merger namun kalah suara, memiliki suatu prinsip yang disebut appraisal remedy atau appraisal rights. Maupun perlindungan hukum secara represif seperti hak mengajukan gugatan secara langsung, hak mengajukan gugatan derivative, hak meminta perseroan dibubarkan dan hak untuk memperoleh keterbukaan informasi.

\section{Daftar Pustaka}

Asmawati. (2014). Perlindungan Hukum Pemegang Saham Minoritas Akibat Merger Bank. Jurnal Ilmu Hukum Jambi, 5(2).

Jusup, A. H. (2011). Dasar-Dasar Akuntansi Jilid 1 Edisi 7. Yogyakarta: STIE YKPN.

Rastuti, T. (2015). Seluk Beluk Perusahaan \& Hukum Perusahaan. Bandung: PT. Refika Aditama.

Sutedi, A. (2015). Buku Pintar Hukum Perseroan Terbatas. Jakarta: Raih Asa Sukses. 